DOI No: http://dx.doi.org/10.29228/Joh.51065

Authenticity process is conducted by

Makale Türü: Araştırma makalesi

Geliş Tarihi: 25-04-2021

Kabul Tarihi: 24-08-2021

On-line Yayın: 31-08-2021

Article Type: Research article Submitted: 25-04-2021

Accepted: 24-08-2021

Published Online: 31-08-2021

Attf Bilgisi / Reference Information

Şahin, S. \& Çalış Toktanış, N. (2021). A Research of Studies Conducted in Turkey Regarding the Social-Emotional Adjustment in Preschool. Journal of History School, 53, 2800-2825.

\title{
A RESEARCH OF STUDIES CONDUCTED IN TURKEY REGARDING THE SOCIAL-EMOTIONAL ADJUSTMENT IN PRESCHOOL ${ }^{1}$ Seda ŞAHIN ${ }^{2} \&$ Nuran ÇALIŞ TOKTANIŞ ${ }^{3}$
}

\begin{abstract}
The development progress of children in the preschool period is quite fast. In this period, they acquire social and emotional skills thanks to the support of their parents at home and preschool teachers at school. By means of the social skills acquired, children adapt socially both to the school and to their peers. Social-emotional adjustment is especially important for children's early socialization. This study aimed to determine the socialemotional adjustment of preschool children by examining the distributions of the research conducted in the body of literature in Turkey, according to the publishing types, models, working groups, issues, data collection tools, and data analysis methods. The research was prepared by examining a total of 32 studies including 21 masters', three doctoral dissertations, and eight articles, which included the phrase "social-emotional adjustment " between 2006 and 2020, they were scanned in the YÖK thesis center, Google Academic and Ulakbim databases. Content analysis method was used in the analysis of the data. The analyzes conducted show that there were no studies on social emotional adjustment in the pre-school period in 2009 and 2011; researches are mostly done in scanning model; Although the study group was composed of children, mostly the data were taken from

\footnotetext{
${ }^{1}$ Author impact rate for article writing: 1 st author: \%60, 2nd author: $\% 40$.

${ }^{2}$ Assistant. Professor., Inonu University Education Faculty Department of Primary Education, Preschool Education Program, seda.sahin@ inonu.edu.tr, Orcid: 0000-0002-4034-7864

${ }^{3}$ Master of Science, Ağrı Directorate of National Education, İsmet Ömeroğlu Primary School, Assistant Director, nuran.calis@gmail.com, Orcid: 0000-0002-0969-9466
} 
A Research of Studies Conducted in Turkey Regarding the Social-Emotional...

teachers and mothers; Among these studies, studies that associate the social emotional adjustment of children with parenting roles and intra-family relationships are predominant; It has been revealed that "Marmara Social Emotional Adaptation Scale" is used in 25 of these studies to determine the social emotional adjustment of children.

Keywords: Preschool Period, Social and Emotional Adjustment, Social and Emotional Development, Research Literature.

\section{Okul Öncesi Dönemde Sosyal-Duygusal Uyum Konusunda Türkiye'de Yapılan Araştırmalara Yönelik Bir İncelenme}

\section{$\ddot{\mathbf{O} z}$}

Okul öncesi dönemde çocukların gelişim seyri oldukça hızlı olmaktadır. Bu süreçte çocuğun sosyal duygusal gelişiminde evde ebeveynlerinin okulda ise okul öncesi öğretmenlerinin sunduğu destek sayesinde çocuklar sosyal ve duygusal beceriler edinmektedir. Edindiği sosyal beceriler sayesinde çocuk hem okula hem de akranlarına sosyal duygusal uyum sağlamaktadır. Sosyal duygusal uyum çocukların erken yıllardaki sosyalleşmeleri açısından oldukça önemlidir. Bu çalışma da okul öncesi dönem çocuklarının sosyal duygusal uyumlarını belirlemek amacıyla Türkiye'deki alanyazında yapılmış araştırmaların yıllarına, yayın türlerine, modellerine, çalışma gruplarına, konularına, veri toplama araçları ve veri analiz yöntemlerine göre dağılımlarını incelemek amacıyla yapılmıștır. Araştırmada 2006 ile 2020 yılları arasında yapılmış "sosyal duygusal uyum" söz öbeğini içeren ve YÖK tez merkezi, Google Akademik ve Ulakbim veri tabanlarında taranan 21 yüksek lisans, 3 doktora tezi ve 8 makale olmak üzere toplam 32 çalışma incelenerek hazırlanmıştır. Verilerin analizinde içerik analizi yönteminden yararlanılmıştır. Yapılan analizler 2009 ve 2011 yıllarında okul öncesi dönemde sosyal duygusal uyum konusunda çalışmalara rastlanmadığını; araştırmaların çoğunlukla tarama modelinde yapıldığını; çalışma grubunu çocukların oluşturmasına rağmen çoğunlukla verilerin öğretmen ve annelerden alındığını; bu çalışmalar içinde çocukların sosyal duygusal uyumunu ebeveynlik rolleri ve aile içi ilişkileri ile ilişkilendiren çalışmaların ağırlıkta olduğunu; “Marmara Sosyal Duygusal Uyum Ölçeği'nin bu çalışmaların 25'inde çocukların sosyal duygusal uyumlarını belirlemek amacıyla kullanıldı̆̆ını ortaya koymuştur.

Anahtar Kelimeler: Okul Öncesi Dönem, Sosyal ve Duygusal Uyum, Sosyal ve Duygusal Gelişim, Araştırma Literatürü

\section{INTRODUCTION}

Education and experiences in the first years of life have a significant impact on later learning ability and future success. The early years, in which certain skills and behaviors that form the basis of human life are acquired, have great 


\section{Seda ŞAHIN \& Nuran ÇALIŞ TOKTANIŞ}

importance in human life because the child's learning speed is extremely high and his mental abilities develop and form rapidly (Gürkan et al., 2010; Koçyiğit, 2012; Oktay, 2007;). It is extremely important to spend this period with appropriate experiences in the best way.

In preschool education, the child gets away from the home environment where the child is at the center and where all the attention is on, spends time with peers, and experiences different activities with them. It is also a process that includes a wide range of opportunities in terms of learning by doing-living the rules of life, sharing interest and love, acting with a group, and learning to wait and be patient (Bilgin, 2012; Hayden, 2009). In addition, preschool years support the development of personality structure, positive self-perception, communication ability, and creativity by affecting all developmental areas as well as the cognitive, physical, social, and emotional development of the child (Gülaçt1, 2014).

Recent studies reveal that social and emotional skills acquired in the preschool period and their competence in these skills support children's interaction with their peers, develop friendship relationships, establish close relationships with their teachers at school, and are successful academically and socially (McCabe and Altamura, 2011).

Children do not come to the world with social skills and socialization. First of all, children learn some of the values and rules of the society and how to comply with them through the various behavior patterns shown by their parents in the family they were born into and, if any, relationships between siblings (Başal, 2012; Deater-Deckard et. al., 2002). Although social development is a concept that is handled together with emotions, the expression 'social emotional development' has turned into a phrase in the literature. Social cohesion is also in relation to emotional adjustment, and they directly affect each other. For this reason, the concept of social adjustment is used together with emotional adjustment, and it is included in the literature as the phrase "social-emotional adjustment ".

Social emotional adjustment is a process that starts from the day the child is born and continues throughout his/her life. Children's social-emotional adjustment behaviors are influenced by parents 'experiences and behaviors during the child-rearing process, such as parents' parental attitudes, mothers 'motherhood styles, child-rearing styles, family communication styles, parents' compatibility with each other, and marital satisfaction (Altınok, 2017; Atan, 2016; Aydın, 2018; Birleşik and Samur, 2017; Çetin, 2019; Çetinkaya, 2016; Demir et al., 2017; Gökçe, 2013; Işık, 2006; Kotil, 2010; Şentürk, 2007). In addition, children 
A Research of Studies Conducted in Turkey Regarding the Social-Emotional...

who grow up in families with parents who show secure attachment and fathers who share cores with the mother in childcare show more social-emotional adjustment than their peers (Barone et al., 2017). For this reason, all educational institutions, especially pre-school education institutions, where the child is in constant interaction with along with the family significantly affect the levels of social-emotional adjustment. The child increases the behaviors approved by the family and decreases disapproved behaviors over time and reflects the social behaviors learned in the family when he/she starts school.

In the early years of school, the most important social context for children outside the home is the classroom. Children's positive interactions with teachers and their classmates create a sense of trust in their selfs. Besides, while meeting the need to spend time with their peers by participating in group games in the school environment, the child also gains skills such as assertiveness, responsibility, starting and maintaining a relationship, cooperation, self-control, planning, expressing feelings, and working with the group (Günindi, 2008; Kulaksızoğlu, 2015; Toran, 2011). Since the child is a member of a group, she/he learns about the features she/he does not know about herself/himself and has a more realistic view of her/his own self. By discovering their abilities, they see what kind of contributions they make to the group in the social environment, discover their strengths and weaknesses, and face social experiences such as acceptance or exclusion (Sevinç, 2009). In addition, as children spend more time in preschool education institutions, positive social behaviors such as sharing, cooperating, protecting their rights while protecting the rights of others increase (Yörükoğlu, 2016). In this respect, preschool education also contributes to the socialization of the child by supporting social-emotional adjustment (Wang et al, 2016).

Social-emotional adjustment has become an issue that attracts attention in our country in recent years. In the literature, it has been determined that many studies on social-emotional adjustment in pre-school period with children and their parents who contribute to children's social-emotional adjustment skills (Altınok, 2017; Atan, 2016; Atan and Buluş, 2018; Bilici, 2019; Can, 2019; Çetin, 2019; Dikici, 2016; Iş1k, 2006; İpek, 2014; Kacır, 2015; Kotil, 2010; Malıyok, 2018; Sezici and Yiğit, 2019; Y1ldırım and Karaman, 2016) have been conducted. In these studies, social problem-solving skills of social-emotional adjustment (Bilici, 2019), parents' child-rearing attitudes and marital conditions (Altınok, 2017; Atan, 2016; Atan and Buluş, 2018; Çetin, 2019; Dikici, 2016; Iş1k, 2006; Kotil, 2010), competition styles (Bilici, 2019), interpersonal problem-solving skills (Dalkılıç, 2019), gender roles (Can, 2019) educational drama practices (Güner, 2008), emotional intelligence of mothers (Güney, 2019), values 
education (İpek, 2014), educational games (Kac1r, 2015), dance education (Malıyok, 2018), behavioral problems (Ramazan and Unsal, 2012), social skill level (Yildirım and Karaman, 2016) and the child's relationship with subjects such as toys (Sezici and Yiğit, 2019) have been investigated. When the literature is examined, no research has been found that reveals the characteristics of the studies on social-emotional adjustment in the preschool period and in what direction the trends are in these studies. The need to examine studies on this subject constitutes the problem of this research. This study, in which the content analysis of the studies on social-emotional adjustment in the preschool period, is expected to be a guide for the researchers. In addition, including in which samples and subjects the studies on social emotional adjustment are concentrated, it is expected to contribute to the pre-school education literature in terms of revealing the areas that have not been studied in the elucidation of the subject.

The main purpose of this research is to examine studies on socialemotional adjustment in early childhood. Within the framework of this main purpose, answers to the following questions were sought;

1. What is the distribution of studies according to their year of publication?

2. What is the distribution of studies according to their type of publication?

3. How is the distribution of the studies according to their models?

4. How is the distribution of studies according to their study group?

5. How is the distribution of the studies according to their subjects?

6. How is the distribution of studies according to data collection tools?

7. How is the distribution of studies according to data analysis methods?

\section{METHOD}

This study which examined the studies on the social-emotional adjustment in preschool in Turkey was conducted with qualitative research methods. The most important benefit of this method for researchers is that it provides the opportunity to use qualitative data collection methods such as observation, interview, and document analysis. Again, in this research, using document analysis as one of the qualitative research methods, studies obtained through various data collection methods were analyzed within the framework of research questions (Yıldırım and Şimşek, 2016). 
A Research of Studies Conducted in Turkey Regarding the Social-Emotional...

\section{Data Collection}

In January 2021, 10 articles and 32 theses belonging to the years 20062020 were reached in the screening on social emotional adjustment in preschool period. While screening, the phrase "social-emotional adjustment " was scanned in related databases, among these, studies related to preschool children were selected and included in the study. Studies conducted at different educational levels were excluded. "Ulakbim" and "Google Scholar" databases were used to reach the articles used in the study, and "YÖK National Thesis Center" was used to access academic dissertations. Two articles and eight theses whose titles included social adjustment, social skills, adjustment to school, social and emotional development were excluded from the evaluation. 32 studies with "social-emotional adjustment " in the title were included in the study.

\section{Data Analysis}

Content analysis was used in the analysis of the data collectes in this study. Content analysis is performed to determine the presence of certain words or concepts in a text or set of texts (Büyüköztürk, Kılıç Çakmak, Akgün, Karadeniz and Demirel, 2019). The researchers classified the collected data in this study in line with the research questions and realized that some concepts were formed in this way, that there were certain semantic relationships between them, and made inference.

After reaching the researches on social-emotional adjustment in the preschool period and deciding which researches to use, the researches were put in order to start with the theses first. The listed researches are numbered by giving codes (For example; A1, A2, A3 ...). The list of studies used to analyze in the study is given in Table 1 .

\section{Table 1}

Studies Examined Within the Scope of the Research

\begin{tabular}{ccll}
\hline No & Type & Author & \multicolumn{1}{c}{ Study title } \\
\hline A1 & Thesis & $\begin{array}{l}\text { Altinok, M. } \\
(2017)\end{array}$ & $\begin{array}{l}\text { The relationship between motherhood styles and preschool } \\
\text { children's social emotional adjustment and academic self- } \\
\text { esteem. }\end{array}$ \\
An2 Thesis & $\begin{array}{l}\text { Bilici, H. S. } \\
\text { (2019) }\end{array}$ & $\begin{array}{l}\text { Analyzing the relationship between social emotional } \\
\text { adaptation, social problem-solving skills and competition } \\
\text { types of } 60-72 \text { months old children attending preschool } \\
\text { education }\end{array}$
\end{tabular}




\section{Seda ŞAHIN \& Nuran ÇALIȘ TOKTANIŞ} A3 Thesis $\begin{aligned} & \text { Çetinkaya, N. } \\ & \text { (2016) }\end{aligned}$

A4 Thesis M. (2014)

A5 Thesis

Dikici, Ş. T. (2016)

A6 Thesis

Gökçe, F. (2013)

A7 Thesis Güner, A. Z. (2008)

A8 Thesis Güney, M. (2019)

A9 Thesis İpek, E. (2014)

A10 Thesis Iş̧k, B. (2006)

A11 Thesis

A12 Thesis

A13 Thesis

A14 Thesis

A15 Thesis

A16 Thesis

A17 Thesis

A18 Thesis

A19 Thesis Atan, A. (2015)

Kaya Değer,

Z. (2019)

Kotil, Ç.

(2010)

Malıyok, G. (2018)

Şentürk, S. (2007)

Topçu Bilir, Z. (2019)

Ünsal, F. Ö. (2010)

Asar, $\mathrm{H}$. (2019)
Dalkılıç, N.

4-5 years old and investigation of preschool children's social-emotional effects of the adoption of the attitude of parents raising (Kars's example)

Comparative of interpersonal problem-solving abilities of children attending preschool education and their social emotional adaptation

The investigation of the effects of parental attitudes on socioemotional adjustment levels of 5-6-year-old children with autism spectrum disorders

Analyzing the social-emotional accordance of 5-6-yearold children with the parenting attitudes of their mothers

Effects of educational drama performances on socialemotional adaptations of children at 5-6 years-old

The investigation of the relation between the social emotional adaptation of the 60-72 months old children and the emotional intelligence of their mothers

A study of the effect of values education program delivered to five years old kids on their social emotional adaptation levels

Organizational and structural quality of family's effect on 60-72-month children's socio-emotional adaptation level

Kacir, O. The effects of educational games on 60-72-month-old

kid's social and emotional adaptation

Examining the social emotional adaptation skills of early childhood Syrian children according to different variables The effects of mother's parental self-efficacy and adjustment to school expectations on social-emotional adjustment of 5-year-old children who have just started preschool

The effects of dance education, applied to 5-year-old preschool children on their socio-emotional adaptation

The comparison among social and emotional adaptation levels of the children aged 5-6 together with child raising attitudes of the mothers working and not working

The effect of life skills programme on five years old children's life skills, self-perception and social emotion adaptation

The relation between social-emotional adaptation and behavior problems of 60-72 months old children whor are attending a pre-school institution

The effect of preschool values education program on social emotional adjustment and value levels of 5-6 age children

The effects of family communication skills psychoeducational program on parents' communication skills, dyadic adjustment, marital satisfaction, and their 56 years old children's social-emotional adjustment 
A Research of Studies Conducted in Turkey Regarding the Social-Emotional...

\begin{tabular}{|c|c|c|}
\hline Thesis & $\begin{array}{l}\text { Aydın. A. } \\
\text { (2018) }\end{array}$ & $\begin{array}{l}\text { Investigation of the relationships between the levels of } \\
\text { social emotional adjustment of 5-6 years old preschool } \\
\text { children, parents' marital satisfaction and family resiliency }\end{array}$ \\
\hline Thesis & $\begin{array}{l}\text { Buharal1, S. } \\
\text { (2019) }\end{array}$ & $\begin{array}{l}\text { The activity of the children centered on positive } \\
\text { development of children's social emotional awareness } \\
\text { levels }\end{array}$ \\
\hline Thesis & $\begin{array}{l}\text { Can, G. İ } \\
(2019)\end{array}$ & $\begin{array}{l}\text { Examination of the relationship between gender-role } \\
\text { behaviors and social-emotional adaptation level of 5-6- } \\
\text { year-old children who receive preschool education }\end{array}$ \\
\hline Thesis & $\begin{array}{l}\text { Çetin, N. } \\
\text { (2019) }\end{array}$ & $\begin{array}{l}\text { Investigation of the relationship between social emotional } \\
\text { adaptation, parents' marriage satisfaction and ego situation } \\
\text { of children under five-six years of preschool education }\end{array}$ \\
\hline Thesis & $\begin{array}{l}\text { Erten } \\
\text { Sar1kaya, H. } \\
(2020)\end{array}$ & $\begin{array}{l}\text { The effect of the preschool teachers' communication skills } \\
\text { psycho-education program on teachers' communication } \\
\text { skills and social-emotional adjustment levels and prosocial } \\
\text { behaviors of five-year-old children }\end{array}$ \\
\hline
\end{tabular}

Demir, T.,

Ocak

A25 Article Karabay, Ş. \&

Sahin As1, D.

The relationship between 5 years old children's social emotional consistency and their parents' attitudes

A26 Article

Güven, Y., \& The validity and reliability of Marmara Scale of Social and Işık, B. (2006) Emotional Adaptation for 5-year-old children

Durmuşoğlu

Saltal1, N.,

A27 Article Arslan, E. \&

Arslan, C.

(2018)

Ramazan, O., A study on the relationship between the social-emotional

A28 Article and Unsal, O.

Sezici, E. \&

An investigation of self-esteem, socio-emotional adaptation and relational problem solving in pre-schoolers

A study on the relationship between the social-emotional
adaptation and behavioral problems of $60-72$-month-old preschoolers

Assessment of the relationship between toy preferences of

A29 Article Yiğit, D.

(2019)

preschool children and their play behaviors and social emotional states

Y1ldirım, G.

A30 Article and Karaman,

N. N. (2016)

Atan, A. \&

A31 Article Buluş, M.

Buluş, M. \&

A32 Article Samur, A. Ö.

(2017)

Analyzing of the relationship between social skills and social emotional adjustment in preschool children

The effect of family communication skills psychoeducational program on 5-6 years old children's socialemotional adjustment

The role of respect for parental self, essential needs and selfefficacy in predicting the social emotional adjustment of five/sixyear-old children

The investigated studies were subjected to content analysis using an inductive method within the framework of seven research questions. For this, first of all, a table was created in Microsoft Word in order to analyze the researches reached through scanning. This table includes the year of the research, type of 
publication, model, subject, study group and data collection tools. After each study was examined, information about the research was recorded in the relevant field in the table. For analysis, themes for each research question were created in the Microsoft Excel program. While creating the analysis findings of the data, frequency information and percentages were used for each research question, and these information were presented in tables in the presentation of the findings.

\section{FINDINGS AND INTERPRETATION}

The first research question of this study, which was conducted to examine the researches on social-emotional adjustment in the preschool period, was about the distribution of the years of publication of the studies. The findings regarding the publication years of the researches examined in this direction are given in Table 2.

\section{Table 2}

Distribution of Studies by Publication Year

\begin{tabular}{|c|c|c|}
\hline Publication year & $\mathrm{f}$ & $\%$ \\
\hline 2006 & 2 & 6,25 \\
\hline 2007 & 1 & 3,13 \\
\hline 2008 & 1 & 3,13 \\
\hline 2010 & 2 & 6,25 \\
\hline 2012 & 1 & 3,13 \\
\hline 2013 & 1 & 3,13 \\
\hline 2014 & 2 & 6,25 \\
\hline 2015 & 1 & 3,13 \\
\hline 2016 & 4 & 12,5 \\
\hline 2017 & 3 & 9,38 \\
\hline 2018 & 4 & 12,5 \\
\hline 2019 & 9 & 28,13 \\
\hline 2020 & 1 & 3,13 \\
\hline Total & 32 & 100 \\
\hline
\end{tabular}

As seen in Table 2, the distribution of 34 studies by years is as follows; one study (3.13\%) in 2007, 2008, 2012, 2013, 2015 and 2020, two studies in 2006, 2010 and $2014(6.25 \%)$, three studies (9.38\%) in 2017, four studies (12.5\%) in 2016 and 2018, and nine studies (28.13\%) in 2019 were conducted. No studies were conducted on social-emotional adjustment in the pre-school period in 2009 and 2011. It was determined that the most work was done in 2019, while in 2020, there was very little work done compared to the previous year. It is thought that the pandemic may have been effective in the low number of researches on the subject in 2020. 
A Research of Studies Conducted in Turkey Regarding the Social-Emotional...

The second research question of the study is about determining the distribution of the types of publications of research on social-emotional adjustment in the preschool period. The findings regarding the analysis made accordingly are given in Table 3.

\section{Table 3}

Distribution of Studies According to Publication Types

\begin{tabular}{lcr}
\hline Publication type & $\mathrm{f}$ & $\%$ \\
\hline Master's thesis & 21 & 65,63 \\
Doctorate thesis & 3 & 9,38 \\
Article & 8 & 25 \\
\hline Total & 32 & 100 \\
\hline
\end{tabular}

As seen in Table 3, 21 master theses $(65.63 \%)$, three doctoral theses $(9.38 \%)$, and eight articles (25\%) were written on social-emotional adjustment in the preschool period. It has been determined that the studies are mostly done as a master's thesis. The fact that the number of Ph.D. thesis numbers in the field of pre-school education in Turkey was low is thought to be due to the absence of the doctoral program.

Determining the distribution of the models of research on social-emotional adjustment in the preschool period is another research question. The findings obtained from the analysis of the research models are presented in Table 4.

\section{Table 4}

Distribution of Studies according to their Models

\begin{tabular}{lrr}
\hline Research model & $\mathrm{f}$ & $\%$ \\
\hline Scanning & 22 & 68,75 \\
Experimental & 8 & 25 \\
Scale adaptation study & 1 & 3,13 \\
Explanatory sequential mixed pattern & 1 & 3,13 \\
\hline Total & 32 & 100 \\
\hline
\end{tabular}

As seen in Table 4, 22 (68.75\%) of 32 studies examined in this study were conducted according to the scanning model, and eight (25\%) according to the experimental research model. One of the studies $(3.13 \%)$ were scale adjustment studies and one study (3.13\%) was conducted in an exploratory sequential mixed design. In studies on social-emotional adjustment in the preschool period, it was determined that the scanning model was mostly preferred, and the least preferred method was the exploratory mixed design. 
Another research question is aimed at determining the study group distribution of studies on social-emotional adjustment in the preschool period. The analysis findings are given in Table 5.

\section{Table 5}

Distribution of Studies by Study Group

\begin{tabular}{llr}
\hline Study Group & $\mathrm{f}$ & $\%$ \\
\hline Child & 18 & 56,25 \\
Child and mother & 4 & 12,5 \\
Child, mother, and father & 9 & 28,13 \\
Child and teacher & 1 & 3,13 \\
\hline Total & 32 & 100 \\
\hline
\end{tabular}

As seen in Table 5, 18 studies (56.25\%) examined in this study were only with children, 4 studies (12. 5\%) with children and their mothers, 9 studies $(28.13 \%)$ with children and their parents, and one study $(3,13)$, with children and their teachers. Accordingly, it is seen that children are the most preferred group in social-emotional adjustment studies in the preschool period. It has been observed in the studies that social emotional adjustment is mostly investigated in relation to the child herself and the situations related to her parents, and only one study was found among the studies conducted with the teachers.

In the study, the distribution of studies on social-emotional adjustment in the preschool period was also examined. Accordingly, the analysis findings for the subject distribution of the studies are given in Table 6 .

As seen in Table 6, ten different themes have been reached from the content analysis made for the subjects of the research. The social-emotional adjustment of children was mostly investigated by correlating them with parenting roles (parents' child rearing attitudes, parental attitudes, parental self-esteem, and basic needs, parental self-efficacy belief, mother's perception of parental self-efficacy, and school expectations). Emotional intelligence of mothers, emotional intelligence of parents under the theme of parental characteristics; family communication skills, values education, life skills, educational game, educational drama, dance training, and child-centered play therapy under the theme of the effectiveness of the educational program; social skill level of children under the theme of social skills; under the theme of refugee children, the social-emotional adjustment of Syrian children is included. 
A Research of Studies Conducted in Turkey Regarding the Social-Emotional...

Table 6

Distribution of Research by Subject

\begin{tabular}{llcc}
\hline Themes & Codes & $\mathrm{f}$ & $\%$ \\
\hline Parenting roles & Parents' child rearing attitudes & 3 & 8,33 \\
& Parenting attitudes & 3 & 8,33 \\
& Parental self-esteem and basic needs & 1 & 2,78 \\
& Parental self-efficacy belief & 1 & 2,78 \\
& Parental self-efficacy perception of the mother & 1 & 2,78 \\
& Compliance of the mother with school expectations & 1 & 2,78 \\
Marriage and family & Parents' marital satisfaction & 2 & 5,56 \\
institution & Organizational and structural nature of the family & 1 & 2,78 \\
& Parents' family resilience & 1 & 2,78 \\
Parents' & Emotional intelligence of mothers & 1 & 2,78 \\
characteristics & Ego states of parents & 1 & 2,78 \\
The effectiveness of & Family communication skills & 2 & 5,56 \\
the training program & Values education & 2 & 5,56 \\
& Life skills & 1 & 2,78 \\
& Educational game & 1 & 2,78 \\
& Educational drama & 1 & 2,78 \\
& Dance training & 1 & 2,78 \\
Problem solving & Child-centered play therapy & 1 & 2,78 \\
skills & Interpersonal problem-solving skills & 1 & 2,78 \\
& Relational problem-solving skills & 1 & 2,78 \\
Children's & Social problem-solving skills & 1 & 2,78 \\
characteristics & Children's behavioral problems & 2 & 5,56 \\
Social skill & Competition styles & 1 & 2,78 \\
Refugee children & Gender role behaviors & 1 & 2,78 \\
Games and toys & Social skill level of children & 1 & 2,78 \\
Communication & Social-emotional adjustment of Syrian children & 1 & 2,78 \\
skills of teachers & Children's toy preferences and play behavior & 1 & 2,78 \\
\hline Total & Children's social-emotional adjustment and prosocial & 1 & 2,78 \\
\hline & behavior & 36 & 100 \\
\hline & & & \\
& & &
\end{tabular}

Only one study conducted with teachers has been found. In this study, children's social-emotional adjustment and prosocial behaviors were associated with teachers' communication skills. As in this study, it has been determined that social-emotional adjustment is addressed in more than one context in some studies.

Studies on social-emotional adjustment in the preschool period were also examined according to the distribution of data collection tools used in research. The findings obtained regarding this are presented in Table 7. 


\section{Seda ŞAHIN \& Nuran ÇALIŞ TOKTANIŞ}

\section{Table 7}

Distribution of studies by data collection tools

\begin{tabular}{llr}
\hline Data collection tool & $\mathrm{f}$ & $\%$ \\
\hline Measurement tools for children & 25 & 36,76 \\
\hline Marmara Social Emotional Adjustment Scale & 8 & 11,76 \\
Social Competence and Behavior Evaluation Scale & 1 & 1,47 \\
Wally Social Problem-Solving Test & 1 & 1,47 \\
Preschool Competition Scale & 1 & 1,47 \\
Preschool Interpersonal Problem-Solving Test & 1 & 1,47 \\
Preschool Behavioral Problems Screening Scale & 1 & 1,47 \\
Preschool Values Scale & 1 & 1,47 \\
Gender Role Behavior Scale & 1 & 1,47 \\
Relational Problem-Solving Scale & 1 & 1,47 \\
Toy Preference Form & 1 & 1,47 \\
Preschool Play Behavior Scale & 1 & 1,47 \\
Early Childhood Life Skills Scale & 1 & 1,47 \\
Social Skills Evaluation Scale & 1 & 1,47 \\
Social Competence and Behavior Evaluation Scale & 1 & 1,47 \\
Positive Social Behavior Teacher Evaluation Form & 1 & 1,47 \\
Self-Supervision Skill Battery & & \\
\hline Measuring tools for parents & 4 & 5,88 \\
\hline Parental Attitude Scale & 3 & 4,41 \\
Family Life and Child Rearing Attitude Scale & 2 & 2,94 \\
Marital Life Scale & 2 & 2,94 \\
Communication Skills Scale & 1 & 1,47 \\
Bar-On Emotional Intelligence Scale & 1 & 1,47 \\
Family Assessment Scale & 1 & 1,47 \\
Maternal Compliance with School Expectations Scale & 1 & 1,47 \\
Parental Self-Efficacy Scale & 1 & 1,47 \\
Family Resilience Scale & 1 & 1,47 \\
Ego States Scale & 1 & 1,47 \\
Rosenberg Self-Respect Scale & 1 & 1,47 \\
Basic Needs Scale & 1 & 1,47 \\
General Self-Efficacy Belief Scale & 1,47 \\
\hline Measurement tools for teachers & 68 & 100 \\
\hline Effective Communication Skills Scale & & \\
\hline Total & 1 & \\
\hline & 1 & \\
\hline
\end{tabular}

As seen in Table 7, three themes have been reached: measurement tools for children, measurement tools for parents and measurement tools for teachers. In 25 of the studies (36.76\%), the Marmara Social-Emotional Adjustment Scale and in 8 of them (11.76\%) Social Competence and Behavior Evaluation Scale were found to be the most frequently preferred scales. In studies associated with parents, the Parental Attitude Scale was used in four (5.88\%) Family Life and Child Rearing Attitude Scale in three (4.41\%), Marriage Life Scale in two $(2.94 \%)$, and Communication Skills Scale in two (2.94\%) of them as measuring 
A Research of Studies Conducted in Turkey Regarding the Social-Emotional...

tools. This revealed that social-emotional adjustment is mostly investigated in relation to parenting behaviors and interfamily relationships in the family. As a measurement tool for teachers, the Effective Communication Skills Scale was used in only one of the studies $(1.47 \%)$.

Research on social emotional adjustment in the preschool period has also been examined for data analysis. Findings regarding the analysis methods preferred in the studies are presented in Table 8.

\section{Table 8}

Distribution of studies by data analysis methods

\begin{tabular}{llr}
\hline Data analysis method & $\mathrm{f}$ & $\%$ \\
\hline T test & 25 & 32,89 \\
Analysis of variance & 18 & 23,68 \\
Correlation analysis & 19 & 25 \\
Regression analysis & 11 & 14,47 \\
Factor analysis & 1 & 1,32 \\
Ki-square analysis & 1 & 1,32 \\
Content analysis & 1 & 1,32 \\
\hline Total & 76 & 100 \\
\hline
\end{tabular}

As seen in Table 8, T-Test was used in 25 (32.89\%), variance analysis in 18 $(23.68 \%)$, correlation analysis in $19(25 \%), 11(14.47 \%)$ regression analysis, factor analysis in one (1.32\%), Chi-square analysis in one $(1.27 \%)$ and content analysis was used in one study $(1.27 \%)$. It has been determined that T-Test, analysis of variance and correlation analysis are frequently used in studies. Since qualitative studies or mixed studies are included in only one study, content analysis has been the least used analysis method.

\section{ARGUMENT, RESULT AND RECOMMENDATIONS}

It was determined that a total of 32 work in research conducted on preschool children's social adjustment in Turkey and these studies started in 2006 for the first time. No studies conducted in 2009 and 2011 were found among the researches. It was determined that most studies were carried out on the subject were in 2019.

Preschool Education Program, two of its main objectives is to prepare children for primary school by supporting them in all areas of development, was updated in 2013, additions were made to the gains and indicators related to the field of social-emotional development, and this area was also updated (MEB, 2013). It was observed that the studies examined in this study started to increase 
from the first year after the implementation of the 2013 Preschool Education Program started. This may be because the results of the studies conducted on the subject (Çorapç1 et al., 2010; Gökçe, 2013; Güner, 2008; Iş1k, 2006; Şentürk, 2007) started to attract the attention of researchers and the understanding of the importance of children's social-emotional adjustment with the implementation of the program after that date. It was determined that the data of one study published in 2020 (Erten Sarıkaya, 2020) were collected before the pandemic. It is thought that the number of researches has decreased due to the fact that the Covid 19 Pandemic, which affects the whole world, was also seen in our country in 2020, face-to-face education was paused, in order to prevent contamination and protect the health of all individuals people were made to stay at home and depending on the decisions taken in this process, the agenda was focused on the protection of children's health rather than research on social-emotional adjustment.

When the studies were examined, 21 master theses, three doctoral theses and eight articles were reached. The low number of doctoral dissertations has also been encountered in document analysis studies on different subjects in the literature (Can Yaşar and Aral, 2011; Gülay Ögelman and Güngör, 2015; Kaytez and Durualp, 2014). This situation is due to the fact that the number of master's programs in our country is higher than the doctorate programs and accordingly, many scientific experts are trained. The number of articles is also quite low compared to master's theses. In addition, some of the articles on this subject (Atan and Buluş, 2018; Güven and Iş1k, 2006) are in the form of converting thesis studies into articles or developing the scale to be used in the thesis. Considering the importance of the subject, the low number of articles was seen as a major deficiency.

In the studies, it was determined that the scanning model (22) was preferred most, and the experimental model (8) was used less. For this reason, it is thought that it is important to increase the number of experimental studies and to contribute to a better explanation of the social-emotional adjustment of children by focusing on observations, interviews with parents and teachers, and studies with mixed designs.

Considering the study group of the studies, 18 studies were conducted only with children, four studies were conducted with children and their mothers, nine studies were conducted with children, mothers, and fathers, there is only one study examining teachers' contribution to children's social-emotional adjustment. In other studies, only the opinions of teachers about the child were used to determine the social-emotional adjustment of children. No research has been conducted on what kinds of practices teachers do to support children's social- 
A Research of Studies Conducted in Turkey Regarding the Social-Emotional...

emotional adjustment, whether they use practices such as family education and family participation, whether they have information on this issue, and what children do if they have problems in this regard. In the experimental studies on the subject, teachers were excluded from the application, and the experimental study was applied by the researcher. After the researcher who made the application in experimental research leaves the classroom, the teacher's work on the social-emotional adjustment of the children continues. For this reason, research can be conducted where teachers are practitioners, who practice the training given to them, teachers' classroom practices can be examined, or action research can be done.

In the studies examined it is seen that the number of studies in which mothers are preferred as the study group is quite high. The reason for this may be that mothers are more willing to participate in research due to their characteristics of being the person responsible for the care, development and education of the child, which is socially attributed to the mother. Some fathers either do not know how to contribute to the care and development of the child because of their gender roles or leave this task entirely to the mother. Some fathers, on the other hand, come home tired due to the intense working conditions, do not have time to deal with the child and issues that concern the child (Akçınar, 2017), or maybe unwilling to do so. On the other hand, mothers may socially elevate motherhood and think that this is their duty and show mothergating roles towards fathers. Today, the number of mothers and fathers who take responsibility for childcare together is increasing. Therefore, studies that investigate the relationship between paternal roles and the social-emotional adjustment of the child are needed. From this point of view, the contribution of fathers of different socioeconomic and educational levels to the social-emotional adjustment of their children should be investigated.

Considering the place of mother and father in the life of the child, it is seen that the number of studies conducted is insufficient. In contrast to the studies on children in pre-school education institutions in our country, Labella et al. (2019) examined the relationship between the parenting qualities of the parents, who are mostly single or lonely mothers, who are dealing with homelessness, who live in the United States and who are responsible for the child's care, with the socialemotional adjustment of the children. In another study (Deater-Deckard et al., 2002), the relationships between siblings of children with different family characteristics and the relationship between conflict situations in these relationships and children's social-emotional adjustment were examined. Only one of the studies focused on the relationship between teachers' effective communication skills and children's social-emotional adjustment (Erten 
Sarkaya, 2020). However, in the world literature, there are studies that examine the quality of teacher-child relationship in Italy (Sette et. al.,2014), professional competencies and job satisfaction of teachers, and social-emotional adjustment of children in the Netherlands, (Breeman et al., 2015). In our country, studies can be conducted to associate and predict the social-emotional adjustment of children with parent groups with different characteristics or to create and test models of different contexts in the parent-child relationship.

Especially since March 2020, when the Covid 19 pandemic was first seen in our country, many measures have been taken across the country in order to reduce the risk of transmission. One of these is the restriction of children going out (Zeybekoğlu Akbaş and Dursun, 2020). In October 2020, education and training institutions were opened, but with certain measures. One of these measures is to shorten the time children spend at school compared to before the pandemic. Although these limitations have negative consequences on some issues in the development of the child, the curfew restrictions may have enabled children to spend more time with family members in domestic environments, increased the child's sharing with their family, and contributed to the formation of intrafamily interactions. In addition, children in some families may have been away from family members due to their parents' working sectors and the risk of contamination during this period and may have spent the process away from their parents without interacting with each other. It is also significant to investigate how the pandemic process affects the social-emotional adjustment of preschool children in the following days.

When the topics of 32 studies in the research were examined, ten themes emerged. These themes are parenting roles, marriage and family institution, characteristics of parents, the effectiveness of education program, problemsolving skills, characteristics of children, social skills, refugee children, games and toys. When the topics of the studies are examined in general, it has been determined that the intensity of the studies on the effectiveness of the education programs prepared by the researchers, which are thought to be effective on the family-related situations and the social emotional adjustment of the children. In addition, subjects related to problem-solving skills, competitive styles, gender role behaviors, social skills, games, and toys were less preferred in the studies. In the preschool period, social-emotional adjustment can be studied with different subjects such as children's self-regulation skills, academic self-esteem, early thinking skills, communication and language skills. In addition, studies can be conducted on how teachers' professional competencies, self-efficacy beliefs, attitudes towards the teaching profession, and language skills affect children's social-emotional adjustment. 
A Research of Studies Conducted in Turkey Regarding the Social-Emotional...

Two themes emerged in the data collection tools used to determine the level of social-emotional adjustment: measurement tools for children and measurement tools for parents. Marmara Social Emotional Adjustment Scale was used in 24 of the studies to determine the social emotional adjustment of children, and Social Competence and Behavior Evaluation Scale was used in eight of the studies. Marmara Social-Emotional Adjustment Scale was first developed for 6year-old children by Önder et al. (2004) for Turkish children. Later, Güven and Iş1k (2006) conducted a validity and reliability study of the same form for fiveyear-old children and revealed that it is a valid and reliable measurement tool. This scale has been preferred as a measurement tool in many studies because it has been developed in our country and is a valid and reliable scale.

Social Competence and Behavior Evaluation Scale was adapted to Turkish in 2010 and a validity and reliability study was conducted (Çorapçı et. al, 2010). However, it has not been used as widely as the Marmara Social-Emotional Adjustment Scale. Developing different scales can enable the issue of socialemotional adjustment to be addressed within the framework of current developments and to be examined more comprehensively.

In the studies examined in this research, $t$ test, analysis of variance, correlation and regression analysis were generally used. These analyzes were preferred because studies generally looked at the difference or relationship between variables. Unlike these analyzes, after determining the factors affecting social-emotional adjustment, creating a model that indicates the relationships between these factors and conducting research using statistical methods such as structural equation modeling, in which it is investigated whether this model is suitable or not, will contribute to the field.

It was observed that the studies on the social emotional adjustment of preschool children examined in this study were limited in number and focused on certain issues. Although the 21 st century we are in is a process where digitalization is intensely in our lives, considering that human beings are social entities and our social needs will never end, focusing on studies on the subject will contribute to literature. 


\section{Seda ŞAHIN \& Nuran ÇALIŞ TOKTANIŞ}

\section{REFERENCES}

Akçınar, B (2017). Involved Fatherhood and Its Determinants in Turkey. Main Report. Anne Çocuk Eğitim Vakfı.

Altınok, M. (2017). The Relationship Between Motherhood Styles and Preschool Children's Social Emotional Adjustment and Academic Self-Esteem. Unpublished master thesis, Aksaray University Institute of Social Sciences.

Asar, H. (2019). The Effect of Preschool Values Education Program on Social Emotional Adjustment and Value Levels of 5-6 Age Children. Unpublished master thesis, Pamukkale University Institute of Educational Sciences.

Atan, A. (2016). The Effects of Family Communication Skills Psychoeducational Program on Parents' Communication Skills, Dyadic Adjustment, Marital Satisfaction, and Their 5-6 Years Old Children's Social-Emotional Adjustment. Unpublished master thesis, Pamukkale University Institute of Educational Sciences.

Atan, A. \& Buluş, M. (2018). The effect of family communication skills psychoeducational program on 5-6 years old children's social-emotional adjustment. Pamukkale University Faculty of Ecucation Journal, 44, 213230.

Aydin. A. (2018). Investigation of The Relationships Between the Levels of Social Emotional Adjustment of 5-6 Years Old Preschool Children, Parents' Marital Satisfaction and Family Resiliency. Unpublished master thesis, Pamukkale University Educational Science Institutes.

Barone, L., Lionetti, F., \& Green, J. (2017). A matter of attachment? How adoptive parents foster post-institutionalized children's social and emotional adjustment. Attachment and Human Development, 19(4), 323339. https://doi.org/10.1080/14616734.2017.1306714

Başal, H.A. (2012). Development and psychology: How can I raise a happy child? Morpa Kultur.

Bilgin, H. (2012). Communication with the family in pre-school education and guidance to families. G. Uyan1k Balat (Ed.), Introduction to Preschool Education (p226-241). Pegem. 
A Research of Studies Conducted in Turkey Regarding the Social-Emotional...

Bilici, H. S. (2019). Analyzing the Relationship Between Social Emotional Adaptation, Social Problem-Solving Skills and Competition Types of 6072 Months Old Children Attending Preschool Education. Unpublished master thesis, Marmara University Institute of Educational Sciences.

Buharal1, S. (2019). The Activity of The Children Centered on Positive Development of Children's Social Emotional Awareness Levels. Unpublished master thesis, Arel University Institute of Social Sciences.

Buluş, M. \& Samur, A. Ö. (2017). The role of respect for parental self, essential needs and selfefficacy in predicting the social emotional adjustment of five/sixyear-old children. Pamukkale University Faculty of Ecucation Journal, 41, 105-119.

Büyüköztürk, Ş., Kılıç Çakmak, E., Akgün, Ö. E., Karadeniz Ş. \& Demirel, F. (2019). Scientific Research Methods in Education (25 ${ }^{\text {th }}$ Printing). Pegem.

Can, G. I (2019). Examination of The Relationship Between Gender-Role Behaviors and Social-Emotional Adaptation Level of 5-6-Year-Old Children Who Receive Preschool Education. Unpublished master thesis, Pamukkale University Institute of Educational Sciences.

Can Yaşar, M. \& Aral, N. (2011). An overview of postgraduate theses within the field of drama at early childhood education in Turkey. Mehmet Akif Ersoy University Faculty of Ecucation Journal, 22, 70-90.

Çetin, N. (2019). Investigation of The Relationship Between Social Emotional Adaptation, Parents' Marriage Satisfaction and Ego Situation of Children Under Five-Six Years of Preschool Education. Unpublished master thesis, Pamukkale University Institute of Educational Sciences.

Çetinkaya, N. (2016). 4-5 Years Old and Investigation of Preschool Children's Social-Emotional Effects of The Adoption of The Attitude of Parents Raising (Kars's Example). Unpublished master thesis, Kafkas University Institute of Social Sciences.

Çorapçı, F., Aksan, N., Arslan-Yalçın, D. \& Yağmurlu, B. (2010). Emotional, behavioral, and social adjustment screening at school entry: social competence and behavior evaluation-30 scale. Turkish Journal of Child and Adolescent Mental Health, 17(2), 63-74.

Dalkılıç, N. M. (2014). Comparative of Interpersonal Problem-Solving Abilities of Children Attending Preschool Education and Their Social Emotional Adaptation. Unpublished master thesis, Gazi University Institute of Educational Sciences. 
Deater-Deckard, K., \& Dunn, J. (2002). Sibling relationships and socialemotional adjustment in different family contexts. Social Development, 11(4), 571-590. https://doi.org/10.1111/1467-9507.00216

Demir, T., Ocak Karabay, Ş. \& Şahin Ası, D. (2017). The relationship between 5 years old children's social emotional consistency and their parents' attitudes. Journal of Interdisciplinary Educational Research, 1(2), 1-14.

Dikici, SS. T. (2016). The Investigation of The Effects of Parental Attitudes on Socioemotional Adjustment Levels of 5-6-Year-Old Children with Autism Spectrum Disorders. Unpublished master thesis, Beykent University Institute of Social Sciences.

Durmuşoğlu Saltalı, N., Arslan, E. \& Arslan, C. (2018). An investigation of selfesteem, socio-emotional adaptation and relational problem solving in preschoolers. European Journal of Education Studies 5(3), 1-18.

Erten Sarıkaya, H. (2020). The Effect of The Preschool Teachers' Communication Skills Psycho-Education Program on Teachers' Communication Skills and Social-Emotional Adjustment Levels and Prosocial Behaviors of Five-Year-Old Children. Unpublished doctoral thesis, Pamukkale University Institute of Educational Sciences.

Gökçe, F. (2013). Analyzing the Social-Emotional Accordance of 5-6-Year-Old Children with The Parenting Attitudes of Their Mothers. Unpublished doctoral thesis, Çukurova University Institute of Social Sciences.

Gülaçtı, F. (2014). Early childhood and pre-school education in Turkey and in the world. S. Tümkaya \& F. Gülaçtı (Ed), Early childhood Education (p.219). Nobel Akademi.

Gülay Ogelman, H. \& Güngör, H. (2015). Investigating the studies on environmental education in preschool period in turkey: investigating the articles and dissertations between 2000-2014. Mustafa Kemal University Journal of Social Sciences Institute, 12(32), 180- 194.

Güner, A. Z. (2008). Effects of Educational Drama Performances on SocialEmotional Adaptations of Children At 5-6 Years-Old. Unpublished master thesis, Marmara University Institute of Educational Sciences.

Güney, M. (2019). The Investigation of The Relation Between the Social Emotional Adaptation of the 60-72 Months Old Children and The Emotional Intelligence of Their Mothers. Unpublished master thesis, Uludağ University Institute of Educational Sciences. 
A Research of Studies Conducted in Turkey Regarding the Social-Emotional...

Günindi, Y. (2011) The Evaluation of Social Skills of Children Attending to Independent Preschool and Kindergarten. Ahi Evran Üniversitesi Kırşehir Ĕ̈itim Fakültesi Dergisi, 12(1), 133-144.

Gürkan, T., Sağlam, M., Yaşar, Ş., Arıkan, A., Erdoğan, S. \& Gültekin, M. (2010). Preparation to primary school and primary education programs. Anadolu University Publication.

Güven, Y., ve Işık, B. (2006). The validity and reliability of Marmara Scale of Social and Emotional Adaptation for 5-year-old children. M. Ü. Atatürk Education Faculity Journal of Educational Science, 23, 125-142.

Hayden, C. T. (2009). My Child Starts School. Ekinoks.

Iş1k, B. (2006). Organizational and Structural Quality of Family's Effect On 6072-Month Children's Socio-Emotional Adaptation Level. Unpublished master thesis, Marmara University Institute of Educational Sciences.

İpek, E. (2014). A Study of The Effect of Values Education Program Delivered to Five Years Old Kids on Their Social Emotional Adaptation Levels. Unpublished master thesis, Necmettin Erbakan University Health Sciences Institute.

Kac1r, O. (2015). The Effects of Educational Games on 60-72-Month-Old Kid's Social and Emotional Adaptation. Unpublished master thesis, On Sekiz Mart University Institute of Educational Science.

Kaya Değer, Z. (2019). Examining the Social Emotional Adaptation Skills of Early Childhood Syrian Children According to Different Variables. Unpublished master thesis, Marmara University Institute of Educational Sciences.

Kaytez, N. \& Durualp, E. (2014). An overview of postgraduate theses within the field of play at early childhood education in Turkey. International Journal of Turkish Education Science, 2(2), 110-122.

Koçyiğit, S. (2012). Staff in preschool education institues. G. Uyanık Balat (Ed.), Introduction to Preschool Education (p.202-225). Pegem.

Kotil, Ç. (2010). The Effects of Mother's Parental Self-Efficacy and Adjustment to School Expectations on Social-Emotional Adjustment of 5-Year-Old Children Who Have Just Started Preschool. Unpublished doctoral thesis, Marmara University Institute of Educational Sciences.

Kulaksızoğlu, A. (2015). Adolescent Psychology. Remzi Bookstore. 
Labella, M. H., Narayan, A. J., McCormick, C. M., Desjardins, C. D., \& Masten, A.S. (2019). Risk and adversity, parenting quality, and children's socialemotional adjustment in families experiencing homelessness. Child Development, 90(1), 227-244. https://doi.org/10.1111/cdev.12894

Malıyok, G. (2018). The Effects of Dance Education, Applied to 5-Year-Old PreSchool Children on Their Socio-Emotional Adaptation. Unpublished master thesis, Marmara University Institute of Educational Sciences.

McCabe, P. C., \& Altamura, M. (2011). Empirically valıd strategies to improve social and emotional competence of preschool children. Journal of Adolescence, 48(5), 513-540. https://doi.org/10.1002/pits

MEB (2013). Okul Öncesi Eğitim Programı. MEB Temel Eğitim Genel Müdürlüğü.

Oktay, A. (2007). Magic Years of Life. Epsilon.

Önder, A., Güven, Y., Sevinç, M. Aydın, O., Uyanık Balat, G., Palut, B., Bilgin, H. Çağlak, S. \& Dibek, E. (2004). Altı yaş çocukları için Marmara Sosyal Duygusal Uyum Ölçeğinin (MASDU) geçerlik ve güvenirlik çalışması. 1 . Uluslararası Okul Öncesi Eğitim Kongresi, 2004. Marmara University.

Ramazan, O., \& Unsal, O. (2012). A study on the relationship between the socialemotional adaptation and behavioral problems of 60-72-month-old preschoolers. Procedia-Social and Behavioral Sciences, 46, 5828-5832.

Sette, S., Baumgarter, E., \& Schnider, B. H. (2014). Shyness, child-teacher relationships, and socio-emotional adjustment in a sample of Italian preschool-aged children. Infant and Child Development, 23(6), 323-332. https://doi.org/10.1002/icd

Sevinç, M. (2009). Play in Early Childhood Development and Education. Morpa.

Sezici, E. ve Yiğit, D. (2019). Assessment of the relationship between toy preferences of preschool children and their play behaviors and social emotional states. Journal of Academic Research in Nursing, 5(3), 178-187.

Şentürk, S. (2007). The Comparison Among Social and Emotional Adaptation Levels of The Children Aged 5-6 Together with Child Raising Attitudes of The Mothers Working and Not Working. Unpublished master thesis, Marmara University Institute of Educational Sciences.

Topçu Bilir, Z. (2019). The Effect of Life Skills Programme on Five Years Old Children's Life Skills, Self-Perception, and Social Emotion Adaptation. 
A Research of Studies Conducted in Turkey Regarding the Social-Emotional...

Unpublished doctoral thesis, Hacettepe University Institute of Educational Sciences.

Toran, M. (2011). Examination Effects of Montessori Method On Children's Concept Acquisition, Social Adaptation, and Fine Motor Skills. Unpublished master thesis, Gazi University Institute of Educational Science.

Ünsal, F. Ö. (2010). The Relation Between Social-Emotional Adaptation and Behavior Problems of 60-72 Months Old Children Whor Are Attending a Pre-School Institution. Unpublished master thesis, Marmara University Institute of Educational Science.

Wang, C., Hatzigianni, M., Shahaeian, A., Murray, E., \& Harrison, L. J. (2016). The combined effects of teacher-child and peer relationships on children's social-emotional adjustment. Journal of School Psychology, 59, 1-11. https://doi.org/10.1016/j.jsp.2016.09.003

Yildırım, G. \& Karaman, N. N. (2016). Analyzing of the relationship between social skills and social emotional adjustment in preschool children. Turkish Studies, 11(9), 965-978.

Yıldırım, A. \& Şimşek, H. (2016). Quantitative Research Methods in Social Science. Seckin.

Yörükoğlu, A. (2016). Children Mental Health. Ozgur.

Zeybekoğlu Akbaş, Ö., \& Dursun, C. (2020). A Study on Working Mothers of Children Missing Out on Preschool Education During Stay-Home Order. World Children Conference, Ankara. www.worldchildrenconference.org

\section{EXTENDED ABSTRACT}

Purpose: The education and experience gained in the first years of life, have profound effect on the developmental areas of children, as well as their learning ability and academic success in school years. The child who starts pre-school education by moving away from the home environment, where all attention is on, them spends time with his peers, experiences different activities with them, learns the rules of life by doing and living, shares interest and love, and learns to wait and be patient by acting with a group. Because children are not born with social skills, they learn some of the values and rules of society and how to comply with them according to the various behavior patterns and behavior management that family members show them. This process is completed with school life. The 
child's being more active and successful in social life is directly related to the high level of social-emotional adjustment. Children's social-emotional adaptation behaviors are affected by parents' experiences and behaviors during the childrearing process, such as parents' parenting styles, mothers' mothering styles, child-rearing styles, family communication styles, parents' harmony with each other and marital satisfaction. In the first years of school, positive interactions with teachers and peers in the classroom provide a sense of trust in children. By playing group games at school, the child gains skills such as assertiveness, responsibility, initiating and maintaining relationships, cooperation, self-control, planning, expressing emotions, running a task with the group, protecting the rights of oneself and others. Like the family, pre-school education also contributes to the socialization of the child by supporting social and emotional adaptation (Wang et al, 2016).

Method: This study was carried out to determine the social-emotional adjustment of preschool children and to examine the distribution of studies in the literature in Turkey according to years, publication types, models, study groups, subjects, data collection tools and data analysis methods. The research was prepared by examining a total of 32 studies, 21 master's, 3 doctoral theses and 8 articles, which were made between 2006 and 2020, including the phrase "social-emotional adaptation" and scanned in the YÖK thesis center, Google Academic and Ulakbim databases. The studies were put in order by giving codes (for example, $\mathrm{A} 1, \mathrm{~A} 2, \mathrm{~A} 3 \ldots)$ and started with theses. Within the framework of seven research questions, it was subjected to content analysis with an inductive method. Information about the year, publication type, model, subject, study group and data collection tools of the researches were recorded in a table created in Microsoft Word. Frequencies and percentages were used for each research question in the Microsoft Excel program.

Findings: As a result of the research, it was determined that there were no studies on social-emotional adjustment in the preschool period in 2009 and 2011, and most studies were carried out in 2019 and the least in 2020. It was thought that the pandemic process was effective in the low number of studies in 2020. It was determined that the studies were mostly done as a master's thesis. In the studies on social-emotional adaptation in the preschool period, it was determined that the scanning model was preferred more and the least preferred method was the explanatory mixed design. It was found that the most preferred group in the studies was children, but the data on children were mostly collected from mothers. The research found that social-emotional adjustment was mostly investigated in relation to the situations related to the child himself and his 
A Research of Studies Conducted in Turkey Regarding the Social-Emotional...

parents, and only one study was found among the studies conducted with teachers.

It was determined that children's social-emotional adjustment was mostly investigated by associating them with parenting roles (parental attitudes, parental attitudes, parental self-esteem and basic needs, parental self-efficacy belief, mother's parental self-efficacy perception and compliance with school expectations). The subject of social-emotional adjustment, which has been studied on very different issues related to the characteristics of parents, was studied with teachers in only one study. In this study, children's social-emotional adaptation and prosocial behaviors were associated with teachers' communication skills as well. Social-emotional adjustment has been researched mostly in relation to parenting behaviors and family relationships. "It revealed that the Marmara Social-Emotional Adjustment Scale was used to determine the social-emotional adjustment of children in 25 of these studies. It was determined that the T-Test, analysis of variance and correlation analysis were frequently used in studies, and qualitative or mixed studies were preferred in only one study.

Result and Argument: Despite the importance of the subject, it has been concluded that the number of studies is low. It is thought that the low number of doctoral thesis on the subject is due to the scarcity of doctoral programs in the field of pre-school education in Turkey. The fact that the number of studies in which data about children is obtained from mothers is quite high in the studies examined is thought to be due to the fact that the mother is the person responsible for the care, development and education of the child socially attributed to the mother. In addition, mothers are more willing to participate in research. Since the importance of the father in the child's life is understood, it has been determined that there should be studies in which fathers are preferred as the data source. Parenting roles and social-emotional adjustment of children were mostly investigated in studies. There is a need for research in which social-emotional adjustment is associated with different situations. It has been understood that it is a common scale related to the subject and that different scales should be developed and used. Since it has been determined that scanning models are frequently used in studies, it has been concluded that researches conducted in different research designs (mixed, qualitative, experimental) will contribute to the literature. It has been observed that the studies on social emotional adjustment of preschool children examined in this study are limited in number and focus on specific issues. Although the 21 st century we live in is a process where digitalization has entered our lives intensively, considering that human is a social being and social needs will never end, focusing on studies on the subject will contribute to the literature. 